Additional Perspectives articles for Influenza: The Cutting Edge book collection are available at http://perspectivesinmedicine.cshlp.org/cgi/collection/influenza_the_cutting_edge.

\title{
The Epidemiology, Virology, and Pathogenicity of Human Infections with Avian Influenza Viruses
}

\author{
Dayan Wang, ${ }^{1}$ Wenfei Zhu, ${ }^{1}$ Lei Yang, ${ }^{1}$ and Yuelong Shu ${ }^{1,2}$ \\ ${ }^{1}$ National Institute for Viral Disease Control and Prevention, Collaboration Innovation Center for Diagnosis and \\ Treatment of Infectious Diseases, Chinese Center for Disease Control and Prevention; Key Laboratory for \\ Medical Virology, National Health Commission of the People's Republic of China, Beijing 102206, P.R. China \\ ${ }^{2}$ School of Public Health (Shenzhen), Sun Yat-sen University, Guangdong 510275, P.R. China \\ Correspondence: shuylong@mail.sysu.edu.cn
}

\begin{abstract}
Influenza is a global challenge, and future pandemics of influenza are inevitable. One of the lessons learned from past pandemics is that all pandemic influenza viruses characterized to date possess viral genes originating from avian influenza viruses (AIVs). During the past decades, a wide range of AIVs have overcome the species barrier and infected humans with different clinical manifestations ranging from mild illness to severe disease and even death. Understanding the mechanisms of infection in the context of clinical outcomes, the mechanism of interspecies transmission, and the molecular determinants that confer interspecies transmission is important for pandemic preparedness. Here, we summarize the epidemiology, virology, and pathogenicity of human infections with AIVs to further our understanding of interspecies transmission.
\end{abstract}

nfluenza A viruses are classified into different subtypes based on the major antigenic surface glycoproteins hemagglutinin (HA) and neuraminidase (NA). To date, $16 \mathrm{HA}$ and 9 NA subtypes have been identified in aquatic birds. Aquatic birds are considered the natural reservoir in which avian influenza viruses (AIVs) typically cause asymptomatic infections with high viral replication rates. Some subtypes of AIVs can cause severe disease in poultry, especially in chickens. Based on their virulence in chickens, AIVs are therefore divided into highpathogenicity AIVs (HPAIVs) and low-pathogenicity AIV (LPAIVs) (see fao.org/avianflu/en/ index.html). All HPAIVs are of the H5 or H7 subtypes. LPAIVs of the H5 and H7 subtypes can evolve in poultry to become HPAIVs, causing severe disease and high mortality. In 1878, Perroncito was the first to report a serious outbreak of chicken disease in Italy, which was known as fowl plague, and was confirmed as an AIV of the H7N7 subtype in 1955 (Alexander and Brown 2009). Since then, a substantial number of poultry outbreaks caused by HPAI H5 and $\mathrm{H} 7$ subtype viruses have been reported worldwide, posing a great challenge for the poultry industry.

AIVs have occasionally caused human infections with clinical manifestations ranging from mild illness to severe disease and even death. Although no sustained human-to-human transmission has occurred, human infections

Editors: Gabriele Neumann and Yoshihiro Kawaoka

Additional Perspectives on Influenza: The Cutting Edge available at www.perspectivesinmedicine.org

Copyright (C) 2021 Cold Spring Harbor Laboratory Press; all rights reserved; doi: 10.1101/cshperspect.a038620

Cite this article as Cold Spring Harb Perspect Med 2021;11:a038620 
D. Wang et al.

with AIVs remain a cause for great concern for at least two reasons: First, viruses of the $\mathrm{H} 5$ and $\mathrm{H} 7$ subtypes may cause severe human disease with high case fatality rates (CFRs) (40\%-60\%), and second, recent studies indicate that HPAI H5 viruses require only a few amino acid mutations to become airborne transmissible among ferrets, highlighting the potential pandemic risk caused by AIVs (Herfst et al. 2012; Imai et al. 2012).

\section{EPIDEMIOLOGY OF HUMAN INFECTIONS WITH AIVs}

Because of the species barrier, AIVs rarely infect humans. In recent decades, both HPAIVs and LPAIV s have caused sporadic human infections, which are typically transmitted directly from poultry to humans. HPAIVs (H5N1, H5N6, H7N7, H7N3, and H7N9) and LPAIVs (H7N2, H7N3, H9N2, H7N9, H6N1, H10N7, and H10N8) have all caused human infections (Fig. 1). However, none of these avian viruses has transmitted efficiently among humans.

\section{Human Infections with HPAI H5 Viruses}

In 1997, the first laboratory-confirmed human infection with an HPAI H5N1 virus was documented in a 3-yr-old boy with acute pneumonia and respiratory distress syndrome in the Hong Kong Special Administrative Region (SAR) of China (Fig. 1). This fatal case showed that a purely AIV can cause respiratory disease and death in humans (Claas et al. 1998; Subbarao et al. 1998; Bender et al. 1999). Seventeen patients were subsequently diagnosed, including six fatal cases in Hong Kong. In 2003, human infections with HPAI H5N1 viruses reemerged in Asia (Peiris et al. 2004). Since then, as of September 2019, 861 cases of laboratory-

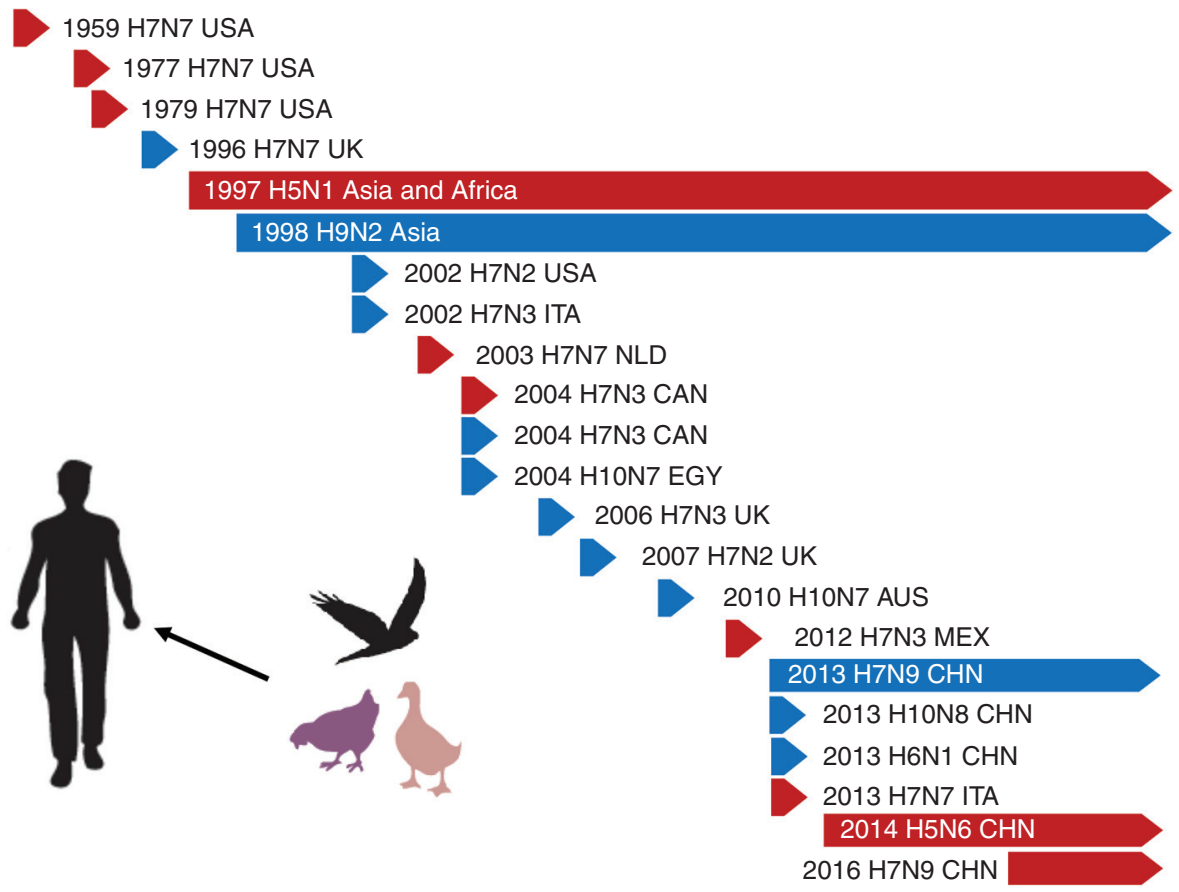

Figure 1. The history of human infections with avian influenza viruses (AIVs). Arrows in red and blue indicate human infections with high-pathogenicity AIVs (HPAIVs) and low-pathogenicity AIVs (LPAIVs), respectively. The length of the arrows represents the time frame during which human cases were reported. (USA) United States of America, (UK) United Kingdom, (ITA) Italy, (NLD) the Netherlands, (CAN) Canada, (EGY) Egypt, (AUS) Australia, (MEX) Mexico, (CHN) China. 
confirmed human infections with highly pathogenic H5N1 AIVs have been reported in 17 countries, including 455 deaths (see who.int/ influenza/human_animal_interface/2019_09_27 _tableH5N1.pdf). Egypt has reported 359 human cases, and China, Indonesia, Vietnam, and Cambodia each have reported more than 50 human cases. Most of the HPAI H5N1 human cases $(\sim 75 \%)$ have occurred in young adults and children (<30 yr of age) (Qin et al. 2015).

In April 2014, the first human infection with an HPAI H5N6 virus (which possessed an HA of the same lineage as HPAI H5N1 viruses) was reported in the Sichuan Province of China (Pan et al. 2016). As of September 2019, 24 HPAI H5N6 human cases have been reported in China, 16 of which were fatal. No HPAI H5N6 human cases have been reported outside China, although poultry outbreaks caused by HPAI H5N6 viruses have been reported in other countries such as Vietnam.

\section{Human Infections with H7 Subtype AIVs}

The first influenza A virus isolate was the fowl plague virus (FPV) isolated from chickens in 1902 (Alexander and Brown 2009). In 1955, it was recognized as an influenza A virus through an antigenicity study of the viral nucleoprotein (NP). This virus is now recognized as an H7N7 subtype influenza virus (A/chicken/Brescia/1902 [H7N7]) (Alexander and Brown 2009).

In 2003, an HPAI H7N7 influenza virus outbreak resulted in the death of tens of millions of poultry in the Netherlands. During this outbreak, 89 poultry workers were infected; most of them presented with conjunctivitis, except one veterinarian who died of severe pneumonia (van Kolfschooten 2003; Fouchier et al. 2004). Two H7N3 human cases were reported in Canada in 2004 (Tweed et al. 2004), caused by HPAI H7N3 and LPAI H7N3 viruses, respectively (Figs. 1 and 2) (Hirst et al. 2004).

In the spring of 2013, the first human infection with an LPAI H7N9 virus was reported in the Yangtze River Delta region of China (Gao et al. 2013b). The virus was not pathogenic to poultry, but most of the laboratory-confirmed human infections resulted in severe illness, and even death (Gao et al. 2013b; Zhang et al. $2013 \mathrm{~b})$. Before the vaccination of poultry was implemented in mainland China, five waves of H7N9 outbreaks occurred (Zhu et al. 2018). During the fifth wave in 2016-2017, the LPAI H7N9 virus evolved into an HPAI H7N9 virus, which caused high mortality among chickens, and also infected humans (Deng et al. 2017; Ke et al. 2017; Yang and Liu 2017; Zhang et al. 2017a). As of September 2019, a total of 1568 laboratory-confirmed H7N9 human cases have been reported, with a CFR of 39\% (Wang et al. 2017) (see chinaivdc.cn/cnic/en/). All human H7N9 cases originated in China; two human H7N9 cases reported in Malaysia and Canada were traced back to travelers from China.

In January 2018, one human infection with an H7N4 subtype AIV was identified in the Jiangsu Province of China (Tong et al. 2018). This was the first human infection with an H7N4 virus. Since then, no additional H7N4 human cases have been reported (Figs. 1 and 2).

\section{Human Infections with H9N2 Subtype AIVs}

The first reported human infections with H9N2 AIVs occurred in Guangdong province in southern China in 1998, including two cases in Shaoguan city and three cases in Shantou city (Guo et al. 1999). The following year, two human infections with H9N2 AIVs were reported in Hong Kong (Peiris et al. 1999). As of September 2019, a total of 35 human infections with H9N2 AIVs have been reported in China, including one fatal case in an individual with underlying disease. Human infections with H9N2 AIVs have also been reported in other countries, including Pakistan, Bangladesh, and Egypt (Figs. 1 and 2). The reported number of human infections with H9N2 AIVs may be an underestimate because of the mild symptoms caused by H9N2 AIVs in humans. Serological studies indicate that additional human infections with H9N2 AIVs have occurred (Lu et al. 2008; Woo and Park 2008; Pawar et al. 2012; Shinde et al. 2012; Zhou et al. 2014; Li et al. 2017). 
D. Wang et al.
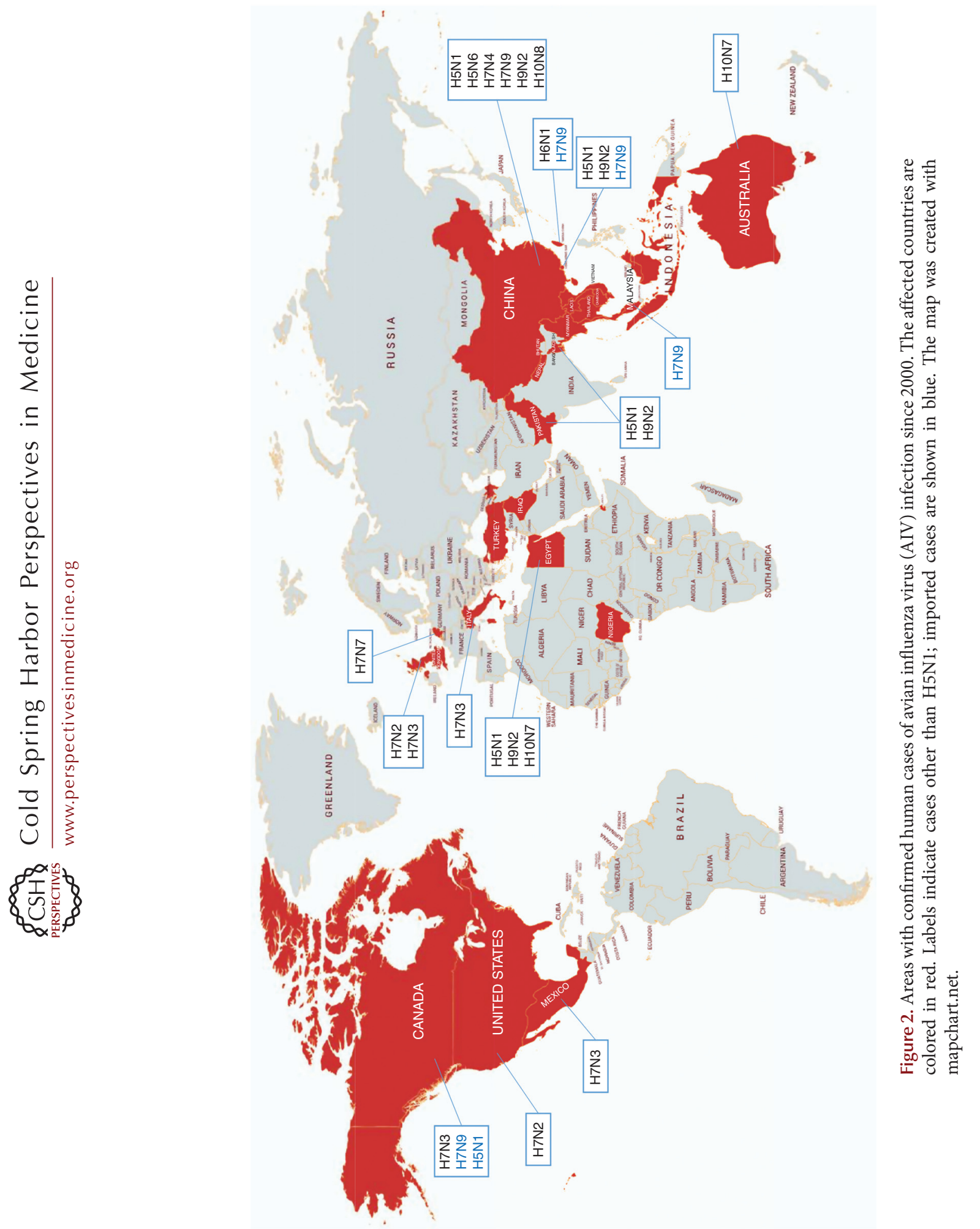


\section{Human Infections with AIVs of Other Subtypes}

In May 2013, the only human infection with an H6N1 virus was reported in Taiwan province, China (Wei et al. 2013). From November 2013 to February 2014, three human infections with $\mathrm{H} 10 \mathrm{~N} 8$ viruses were reported in Jiangxi province, China, two of which were fatal (Chen et al. 2014); since then, no other human infections with $\mathrm{H} 10 \mathrm{~N} 8$ viruses have been reported. Mild human infections with H10N7 AIVs have been reported previously in Egypt and Australia (Figs. 1 and 2) (Organization PAH 2004; Arzey et al. 2012). Serological evidence suggests that AIVs of the H4, H6, and H11 subtypes may also have caused human infections (Shortridge 1992; Peiris et al. 2007).

\section{Comparative Epidemiology of Human Infections with H7N9 and H5N1 AIVs}

Humans are generally not susceptible to AIV infections, mainly because of the differences in the receptor-binding specificity between human and AIVs. As a consequence, AIVs do not easily cross the species barrier to infect humans. However, as described earlier, AIVs occasionally infect humans. A major source of human infections with AIVs are live poultry markets, where people may be exposed to infected birds, to AIVs in the environment, or both (Wan et al. 2011; Han et al. 2013; Shi et al. 2013b). Limited human-to-human transmission of AIVs may have occurred (Olsen et al. 2005), including vertical transmission (Shu et al. 2006).

Most of the (fatal) human infections with AIVs have been caused by viruses of the H7N9 and $\mathrm{H} 5 \mathrm{~N} 1$ subtypes. Human H7N9 infections have mainly affected the elderly of $>60$-yr of age, whereas human $\mathrm{H} 5 \mathrm{~N} 1$ infections primarily have occurred in young adults. The sex ratio of human infections with $\mathrm{H} 5 \mathrm{~N} 1$ virus is balanced, but H7N9 AIVs have infected more males than females (with a ratio of 2:1). The CFR of human infections with H7N9 influenza viruses is 39\%, whereas that of human infections with $\mathrm{H} 5 \mathrm{~N} 1$ influenza viruses is $\sim 60 \%$ (Cowling et al. 2013b; To et al. 2013; Qin et al. 2015).

\section{VIROLOGICAL CHARACTERISTICS OF HUMAN INFECTIONS WITH AIVs}

Typically, all eight viral RNA segments of AIVs that infect humans are derived from AIVs, and there has been no natural reassortment with influenza viruses prevalent in human or pig populations.

\section{Receptor-Binding Profiles of AIVs That Cause Human Infections}

Transmission of AIVs to humans is rare, in part because of host range restrictions that limit influenza virus transmissions between avian species and mammals. The host species restriction and cell and tissue tropism of influenza viruses are determined by several factors, including differences in receptor distribution between avian and mammalian cells and differences in the receptor-binding specificities of human and AIVs. The HA proteins of AIVs typically have a binding preference for sialic acid (SA) residues with an $\alpha-2,3-$ Gal terminating sequence found primarily on the surfaces of epithelial cells in the intestinal tract of ducks. In the human respiratory tract, $\alpha-2,6 \mathrm{SA}$ receptors are predominantly expressed on ciliated cells in the upper respiratory tract (URT), whereas $\alpha-2,3$ SA receptors are mainly present on nonciliated cells of the lower respiratory tract (LRT) and on type II pneumocytes (Fig. 3) (Connor et al. 1994; Shinya et al. 2006; Chandrasekaran et al. 2008). Accordingly, although AIVs can infect humans without a change in receptor-binding specificity, mutations that confer binding to $\alpha-2,6 \mathrm{SA}$ receptors are likely critical to confer sustained human-tohuman transmission. Replication of HPAI H5N1 viruses (which bind to $\alpha-2,3$ SA receptors) in humans is mainly confined to the LRT, which may have limited the number of virus particles expelled through breathing and/or coughing.

Like all subtypes of AIVs, AIVs of the H7 subtype can be subdivided into two genetic lineages according to the geographic origin of the viruses: the North American lineage and the Eurasian lineage, with viruses from both lineages having infected humans (Fig. 1). Most Eur- 
D. Wang et al.
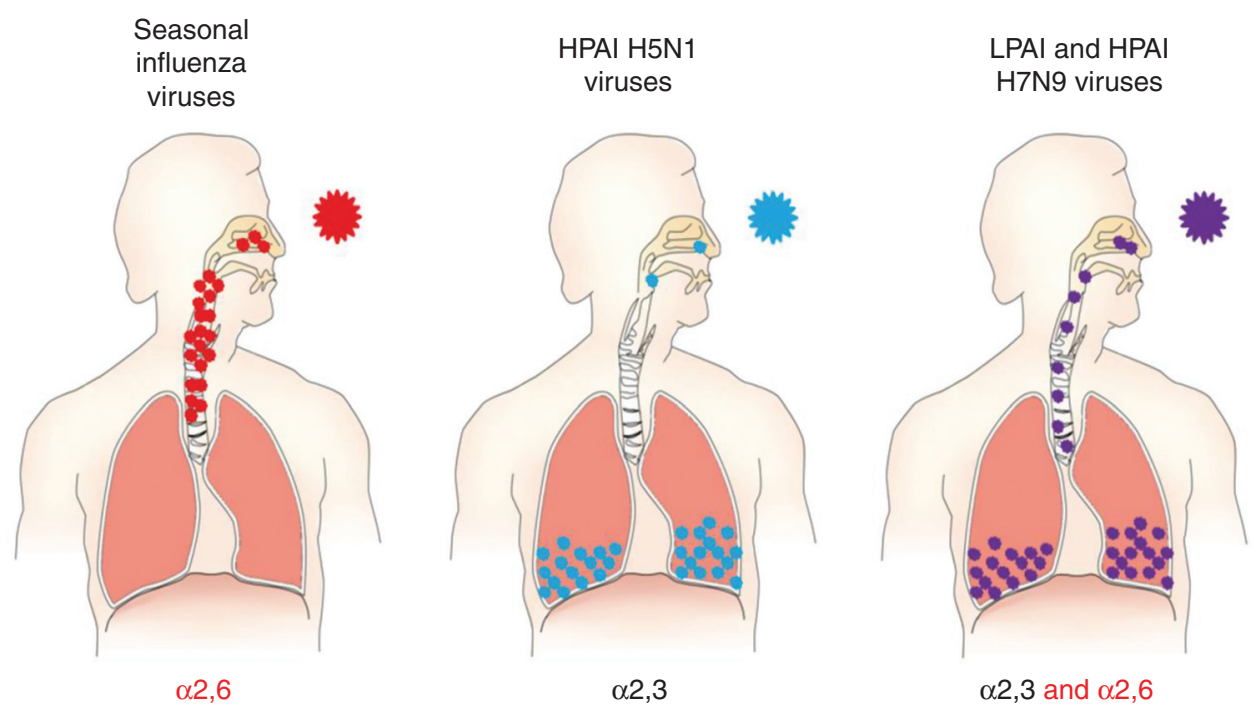

Figure 3. Airway tract tissue tropism illustration and the receptor-binding profiles of seasonal influenza viruses, avian $\mathrm{H} 5 \mathrm{~N} 1$ viruses, and influenza $\mathrm{A}(\mathrm{H} 7 \mathrm{~N} 9)$ viruses.

asian $\mathrm{H} 7$ subtype viruses resemble HPAI H5N1 viruses in their preferential binding to $\alpha-2,3 \mathrm{SA}$ receptors. However, the H7N9 viruses that emerged in 2013 can bind to both SA $\alpha-2,3-$ Gal and SA $\alpha-2,6-$ Gal receptors (Fig. 3) (Shi et al. 2013a; Tharakaraman et al. 2013; Watanabe et al. 2013; Xiong et al. 2013; Zhou et al. 2013). This dual receptor-binding profile may lead to more frequent human infections with H7N9 viruses, as compared with human infections with AIVs of other subtypes.

\section{Key Mammalian-Adapting Molecular Markers of AIVs That Cause Human Infections}

One of the most common amino acid substitutions associated with converting LPAI strains from avian- to mammalian-receptor specificity is the HA Q226L substitution (H3 numbering). For example, LPAI H9N2 isolates from birds can acquire a Q226L substitution that increases the viruses' receptor-binding affinity for mammalian cells and may facilitate the infection of mammalian hosts (Wan et al. 2008). With regard to human isolates of H7N9 viruses, A/Shanghai/1/ 2013 (encoding HA Q226) and A/Anhui/1/2013 (encoding HA L226) bind preferentially to avian $\alpha-2,3-\mathrm{Gal}$ receptor analogs or to both $\alpha-2,3-\mathrm{Gal}$ and $\alpha-2,6-$ Gal receptors, respectively (Yamada et al. 2006; Nidom et al. 2010; Yang et al. 2010; Srinivasan et al. 2013). The Q226L mutation has not been commonly observed in the HA of HPAI H5N1 field isolates. The HA G186V substitution (H3 numbering) is associated with the dual receptor-binding specificity of both HPAI and LPAI influenza H7N9 viruses (Shi et al. 2013a; Zhou et al. 2013; Zhu et al. 2017).

Although receptor-binding specificity is an important factor in the interspecies transmission of influenza viruses, additional factors are involved in the mammalian adaptation of AIVs. In 2012, Herfst and colleagues (Herfst et al. 2012) showed that introduction of the HA Q226L/G228S and PB2 E627K mutations into an $\mathrm{H} 5 \mathrm{~N} 1$ virus did not confer virus transmission via respiratory droplets among ferrets. However, respiratory transmission among ferrets occurred after the virus had been passaged 10 times in ferrets (Herfst et al. 2012), resulting in three additional mutations (PB1 H99Y, HA H110Y, and HA T160A) that might be essential for the viral respiratory droplet transmissibility in ferrets (Linster et al. 2014). In the study by Imai 
et al. (2012), the artificially introduced substitutions HA N224K/Q226L (which confer binding to $\alpha-2,6-\mathrm{Gal}$ receptors) and the additional HA N158D/T318I mutations (which emerged during two passages in ferrets) were required to generate an airborne-transmissible $\mathrm{H} 5$ virus (with the remaining seven segments from the human A/ California/04/2009 H1N1 virus) in ferrets. Mutations at either position 158 or 160 resulted in loss of the N-glycosylation site at 158-160 of HA, which has been shown to affect the receptorbinding profiles and the virulence of HPAI H5 viruses (Herfst et al. 2012; Imai et al. 2012). Moreover, H1N1 virus genes encoding the acidic polymerase (PA) and nonstructural (NS1) proteins rendered the $\mathrm{H} 5 \mathrm{~N} 1$ virus transmissible by respiratory droplets between guinea pigs (Zhang et al. 2013c). Other H1N1 genes, including those that encode the NP, NA, and the matrix (M1) protein, as well as mutations in $\mathrm{H} 5 \mathrm{HA}$ that improve affinity for human-like airway receptors, could enhance the mammal-to-mammal transmission (Zhang et al. 2013c). These reports have established that mutant and/or reassortant $\mathrm{H} 5 \mathrm{~N} 1$ AIVs can transmit among mammals. Analyses of field viruses indicate that some circulating viruses already contain some of the mutations identified in these H5 transmission studies (Russell et al. 2012). Enhanced surveillance should be performed to closely monitor these mutations in zoonotic influenza viruses.

Besides HA-receptor binding, key factors for viral fitness in mammals include substitutions in the viral polymerase proteins, including PB2E627K (Table 1) (Hatta et al. 2001). Avian influenza virus isolates exclusively contain glutamic acid at position 627 in PB2, whereas it is frequently mutated to lysine in human-derived isolates (Fonville et al. 2013; Manz et al. 2013). The PB2-E627K mutation is required for the airborne transmissibility of HPAI H5N1 viruses in ferrets and high viral replication in mice (Hatta et al. 2001; Herfst et al. 2012; Imai et al. 2012). However, avian H5N1 and H7N9 viruses that retained the avian-like glutamic acid at position 627 of PB2 have frequently caused fatal human infections (Zhu et al. 2015), indicating that PB2-E627K is not always strictly necessary for avian viruses to infect mammals.

\section{EMERGENCE, EVOLUTION, AND DISSEMINATION OF AIVs THAT CAUSE HUMAN INFECTIONS}

\section{LPAI H7N9 Viruses}

The influenza A(H7N9) viruses have caused five epidemic waves in humans in China. Since their emergence, studies have been conducted to learn about the viruses' origin and evolution. Most likely, the HA of these viruses originated from a duck influenza virus; the NA was related to $\mathrm{N} 9$ viruses detected in migratory birds, and the six internal genes were from avian influenza H9N2 viruses (Gao et al. 2013b; Liu et al. 2013).

Since the first detection of the novel H7N9 viruses in 2013, the six internal genes have frequently reassorted with those of H9N2 viruses cocirculating in poultry (Wu et al. 2013; Zhang et al. 2013a; Cui et al. 2014; Lam et al. 2015; Wang et al. 2016). From wave III onward, the evolution of the NP gene changed in that it was most frequently derived from cocirculating H7N9 viruses rather than from H9N2 viruses (Zhu et al. 2018). Dynamic reassortment events generated multiple genotypes. Most of these genotypes were transient, although some gradually became dominant. One of the genotypes, ZJ11like viruses, emerged in the late phase of wave III, slightly increased in frequency late in wave $\mathrm{IV}$, and substantially increased in frequency from the beginning of wave V. The ZJ11 genotype viruses accounted for most of the human infections in wave V (Zhu et al. 2018). Overall, the H7N9 viruses have evolved rapidly since their emergence.

A "genetic tuning" mechanism was proposed to explain the possible process of interspecies transmission of avian H7N9 viruses (Fig. 4) (Wang et al. 2014a; Zhu and Shu 2015). Through this process, H7N9 viruses may have first acquired mutations that facilitate replication in poultry before acquiring mutations that facilitate replication in mammals.

\section{HPAI H7N9 Viruses}

Currently, the LPAI H7N9 viruses have evolved into two regionally distinct lineages - the Yangtze Delta lineage and the Pearl Delta lineage- 
D. Wang et al.

Table 1. Molecular markers associated with increased transmissibility in animal models of AIVs

\begin{tabular}{|c|c|c|c|}
\hline Function & Gene & Position and AA & Reference(s) \\
\hline \multirow[t]{18}{*}{$\begin{array}{l}\text { Enhanced binding to } \\
\text { human-type receptor }\end{array}$} & \multirow[t]{9}{*}{ H5 } & $\begin{array}{l}\text { Loss of } \\
\text { glycosylation site } \\
\text { at } 158-160\end{array}$ & Herfst et al. 2012; Imai et al. 2012 \\
\hline & & $186 \mathrm{~K}$ & Chutinimitkul et al. 2010; Yamada et al. 2006 \\
\hline & & $190 \mathrm{D}$ & Chen et al. 2012; Stevens et al. 2006 \\
\hline & & $196 \mathrm{R} / \mathrm{H}$ & $\begin{array}{l}\text { Chen et al. 2012; Watanabe et al. 2011; Yamada } \\
\text { et al. } 2006\end{array}$ \\
\hline & & $222 \mathrm{E} / \mathrm{Q}$ & Guo et al. 2017; Manz et al. 2010 \\
\hline & & $224 \mathrm{~K}$ & Imai et al. 2012 \\
\hline & & $226 \mathrm{~L}$ & $\begin{array}{l}\text { Harvey et al. 2004; Herfst et al. 2012; Imai et al. } \\
\text { 2012; Stevens et al. 2006; Chutinimitkul et al. } \\
2010\end{array}$ \\
\hline & & $227 \mathrm{~N} / \mathrm{R}$ & $\begin{array}{l}\text { Chen et al. 2012; Chutinimitkul et al. 2010; } \\
\text { Gambaryan et al. 2006; Guo et al. 2017; Shinya } \\
\text { et al. } 2010\end{array}$ \\
\hline & & $228 \mathrm{~S}$ & $\begin{array}{l}\text { Chutinimitkul et al. 2010; Harvey et al. 2004; Herfst } \\
\text { et al. 2012; Stevens et al. 2006; Wang et al. } 2010\end{array}$ \\
\hline & \multirow[t]{2}{*}{ H6 } & $225 \mathrm{D}$ & de Vries et al. 2017b \\
\hline & & $226 \mathrm{~L}$ & Qu et al. 2017 \\
\hline & \multirow[t]{6}{*}{$\mathrm{H} 7$} & $\begin{array}{l}\text { Gain of } \\
\text { glycosylation site } \\
\text { at } 133\end{array}$ & Srinivasan et al. 2013 \\
\hline & & $186 \mathrm{~V}$ & $\begin{array}{l}\text { Xiong et al. 2013; Yang et al. 2010; Shi et al. 2013a; } \\
\text { Tharakaraman et al. } 2013\end{array}$ \\
\hline & & $193 \mathrm{~T}$ & de Vries et al. 2017a \\
\hline & & $224 \mathrm{~K}$ & de Vries et al. 2017a \\
\hline & & $226 \mathrm{~L} / \mathrm{I}$ & $\begin{array}{l}\text { Shi et al. 2013a; Srinivasan et al. 2013; } \\
\text { Tharakaraman et al. 2013; Xiong et al. } 2013\end{array}$ \\
\hline & & $228 \mathrm{~S}$ & Srinivasan et al. 2013; Tharakaraman et al. 2013 \\
\hline & $\mathrm{H} 9$ & $226 \mathrm{~L}$ & Wan et al. 2008 \\
\hline \multirow{3}{*}{$\begin{array}{l}\text { Increased polymerase } \\
\text { activity in mammalian } \\
\text { host }\end{array}$} & \multirow[t]{3}{*}{$\mathrm{PB} 2$} & Q591K & Chan et al. 2016; Mok et al. 2014 \\
\hline & & E627K & Herfst et al. 2014; Mok et al. 2014; Zhu et al. 2015 \\
\hline & & $\mathrm{D} 701 \mathrm{~N}$ & Mok et al. 2014; Zhu et al. 2015 \\
\hline
\end{tabular}

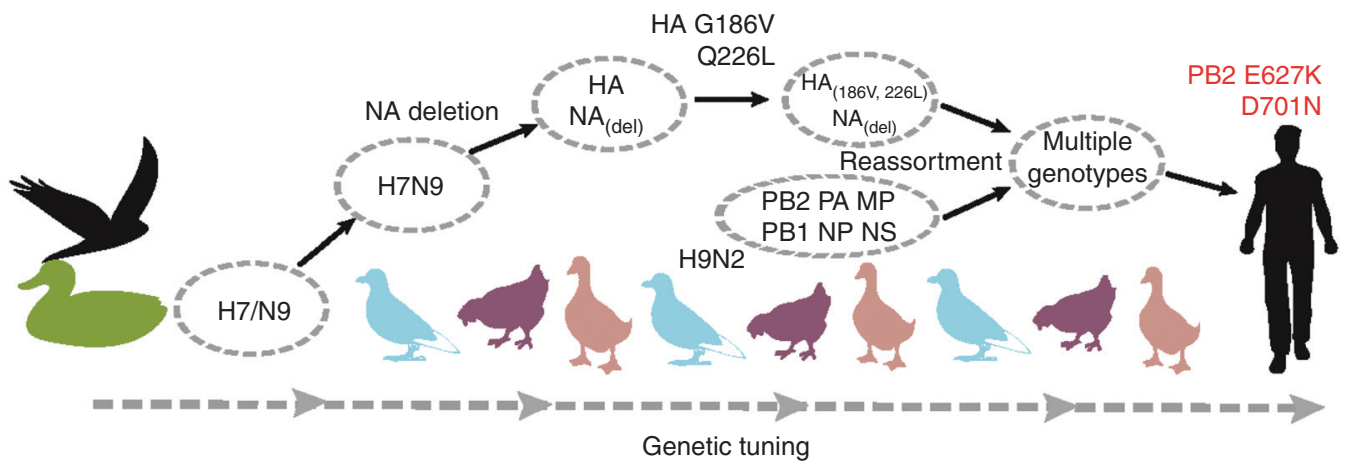

Figure 4. Proposed "genetic tuning" mechanism for influenza A(H7N9) viruses. (Created from data in Wang et al. 2014a and Zhu and Shu 2015.) 
based on the sequences of their HA and NA genes (Wang et al. 2016). Although HPAI H7N9 viruses were first isolated in the Pearl Delta region, they have exclusively belonged into the Yangtze Delta lineage (Ke et al. 2017; Yang et al. 2017). HPAI H7N9 viruses arose from the LPAI H7N9 progenitors. The acquisition of multiple basic amino acids at the HA cleavage site (a hallmark of HPAI, discussed in more detail later) occurred in late May 2016 in the Pearl Delta region. Different motifs of basic amino acids at the HA cleavage site have been detected in HPAI H7N9 viruses in poultry (Shi et al. 2017). In contrast, HPAI H7N9 viruses isolated from humans bear only two types of amino acid insertions (Yang et al. 2017).

Dynamic reassortment of the internal genes of LPAI H7N9 and H9N2 viruses has been broadly reported (Wu et al. 2013; Zhang et al. 2013a; Cui et al. 2014; Lam et al. 2015; Wang et al. 2016). Similar to LPAI H7N9 viruses, HPAI H7N9 viruses also reassorted with LPAI H7N9 or H9N2 viruses in poultry (Yang et al. 2017). Several genotypes emerged that differed in their internal genes. One of these genotypes (Genotype II [Yang et al. 2017]) may have a fitness advantage over the others, because this genotype was the only one to spread from Guangdong province to other regions.

\section{HPAI H5N6 Viruses}

HPAI H5N6 viruses are currently circulating in poultry throughout China and South East Asia and occasionally infect humans in China. The HA gene of H5N6 viruses originated from the clade 2.3.4 HPAI H5N1 viruses that emerged in chickens in China in 2005. In 2007, the HPAI $\mathrm{H} 5$ viruses evolved into clade 2.3.4.4. From 2009 to 2012 , the clade 2.3.4.4. H5 viruses reassorted with waterfowl viruses of different NA subtypes, including $\mathrm{N} 2, \mathrm{~N} 6$, and N8, generating HPAI H5N2/N6/N8 viruses (Yang et al. 2016). Phylogenetic and the "time to most recent common ancestor" (tMRCA) analyses suggested that two independent reassortment pathways generated two subclades of H5N6 viruses between 2011 and 2013. In the first pathway, H5N2 viruses with a clade 2.3.4.4 HA gene may have reas- sorted with an H6N6 virus between mid-2011 and mid-2012 to acquire the N6 NA gene; then, further reassortment might have occurred involving the acquisition of the six internal genes of poultry clade 2.3.2.1c $\mathrm{H} 5 \mathrm{~N} 1$ viruses, generating so-called "Reassortant A" viruses. In the second pathway, reassortment likely occurred among an $\mathrm{H} 5 \mathrm{~N} 8$ virus with a clade 2.3.4.4 HA gene, an H6N6 virus with an NA gene containing a deletion in the stalk region, and poultry clade 2.3.2.1c $\mathrm{H} 5 \mathrm{~N} 1$ viruses, which provided the internal genes; the resulting $\mathrm{H} 5 \mathrm{~N} 6$ virus was designated "Reassortant B." Since 2015, consecutive reassortment events of "Reassortant B" H5N6 viruses with the six internal genes from chicken $\mathrm{H} 9 \mathrm{~N} 2$ viruses have resulted in so-called “Reassortant C” H5N6 viruses (Yang et al. 2016).

All three reassortant viruses have caused human infections. The virus isolated from the first reported H5N6 human case in Sichuan Province in 2014 was a "Reassortant A" virus. Viruses from human cases in Guangdong Province in late 2014 had the gene cassette of "Reassortant B," and human isolates from Yunnan and Guangdong provinces since 2015 have belonged to "Reassortant C." Since then, HPAI H5N6 viruses have continued to evolve. In 2016, two H5N6 viruses were isolated from two patients in China. The internal gene cassettes of these two strains differ from those reported previously, representing two novel genotypes of H5N6 viruses (Zhang et al. 2017b). Another novel influenza H5N6 virus with a unique internal gene cassette was isolated from a patient in Jiangsu province in China in 2018 (unpubl. data). Most likely, novel genotypes of $\mathrm{H} 5 \mathrm{~N} 6$ viruses will continue to emerge.

\section{CLINICAL FEATURES OF HUMAN INFECTIONS WITH AIVs}

\section{Clinical Manifestations}

AIVs generally do not cause clinical symptoms in their natural reservoir, but poultry (such as chickens) infected with HPAIVs usually present with severe syndromes and high mortality. The clinical presentation of human infections with AIVs varies from mild respiratory symptoms 
D. Wang et al.

and conjunctivitis to acute pneumonia and even death. Most humans infected with highly pathogenic H5 AIVs develop a severe illness with a high case fatality rate (Yuen et al. 1998; Uyeki 2009; Shinya et al. 2011). Before 2013, conjunctivitis was the main manifestation of human infections with viruses of the $\mathrm{H} 7$ subtype, with the exception of a fatal human infection with an HPAI H7 virus (Koopmans et al. 2004). Respiratory conditions, including pneumonia and respiratory distress syndrome, are the main manifestations of human infections with the novel H7N9 AIVs (Gao et al. 2013a; Lu et al. 2013; $\mathrm{Yu}$ et al. 2013a,b). Although the novel H10N8 viruses are of the low-pathogenicity type, they can cause serious illness or death (Chen et al. 2014). Symptoms of human infection with $\mathrm{H} 9 \mathrm{~N} 2$ viruses are generally mild, mainly manifested as respiratory symptoms such as fever.

\section{Viral Factors That Contribute to Severe Clinical Symptoms in Infected People}

Pathogenesis is the result of complex interactions between the virus and host, with many factors from both the virus and the host involved in this interplay. Besides the HA-mediated receptor-binding specificity discussed above, key to viral pathogenicity is the presence of a multibasic HA cleavage site (MBCSs). HPAIV generally encode a MBCS at the HA cleavage site (Bosch et al. 1981; Webster and Rott 1987), whereas HAs from mammalian viruses or LPAIV usually encode only a single basic residue at their cleavage site (Garten and Klenk 1999; Klenk and Garten 1994). The presence of the polybasic residues allows the HA to be cleaved by enzymes that are expressed in a wide range of tissues, whereas the cleavage site that contains a single basic residue can only be cleaved by enzymes in the respiratory tract or intestinal tract. Because HA cleavage is required for viral infectivity, the polybasic cleavage site broadens the tissue range of the virus and is strongly associated with systemic spread and increased infectivity and virulence in birds and mammals (Hatta et al. 2001; Tanaka et al. 2003; Suguitan et al. 2012). HPAI H5N1 viruses with an MBCS cause severe infections in hu- mans. Some H7N9 viruses also have acquired an MBCS to become highly pathogenic in chickens. HPAI H7N9 viruses with an MBCS showed increased disease severity in the ferret model compared with an LPAI H7N9 virus (Imai et al. 2017). However, LPAI H7N9 viruses that lack an MBCS still cause severe disease in most human cases (Gao et al. 2013a,b). Thus, the MBCS is a key virulence factor for AIVs in avian species, but not a key determinant for the severity of AIV infections in humans.

Substitutions in the ribonucleoprotein (RNP) complex (which comprises the polymerase subunits $\mathrm{PB} 2, \mathrm{~PB} 1$, and $\mathrm{PA}$ and $\mathrm{NP}$ ) are frequently linked to increased replication and virulence of viruses. PB2 is a major host range determinant of influenza viruses. One of the most critical substitutions is PB2-E627K, which, as already mentioned, contributes to human infections with AIVs. The PB2 E627K mutation is strongly linked to increased virulence in mice of HPAIV H5N1 (Hatta et al. 2001; Maines et al. 2005; Chen et al. 2007), HPAIV H7N7 (Munster et al. 2007), LPAIV H7N9 (Mok et al. 2014; Zhu et al. 2015), and the $1918 \mathrm{H} 1 \mathrm{~N} 1$ virus (Qi et al. 2012).

Most influenza H7N9 viruses isolated from chickens cause no clinical symptoms in mice and are nonlethal in ferrets (Zhang et al. 2013b; Shi et al. 2017). LPAI or HPAI H7N9 viruses isolated from patients cause mild to severe disease or are lethal in these mammal models, respectively (Richard et al. 2013; Watanabe et al. 2013; Zhu et al. 2013; Imai et al. 2017). Of note, an HPAI H7N9 virus was shown to be more pathogenic in mice and ferrets than an LPAI H7N9 virus (Imai et al. 2017). In addition, H7N9 viruses isolated from humans are generally more transmissible in ferrets than those isolated from avian species (Zhang et al. 2013b; Zhu et al. 2013; Imai et al. 2017; Shi et al. 2017). This may be due to mammalian-adapting mutations, including PB2 E627K. Studies have shown that after replication in mice and ferrets, LPAI or HPAI H7N9 viruses isolated from avian species acquired mammalian-adapting mutations such as PB2 E627K or PB2 D701N (Zhu et al. 2015; Shi et al. 2017). However, no such mutations occurred when the virus replicated in chickens. When HPAI H7N9 viruses of avian origin ac- 
quired mammalian-adapting mutations, they became lethal in mice and ferrets and highly transmissible among ferrets (Shi et al. 2017).

Some mutations in PB1 (such as PB1 473V and 598P) and NP (such as NP 357K) have also been found to increase the pathogenicity of AIVs in mammals (Xu et al. 2012; Zhu et al. 2019). Other genes, including those encoding NS1 and the nuclear export protein (NEP), also encode molecular markers associated with pathogenicity. NS1 is critical for natural infection because it inhibits the host innate immune response (Donelan et al. 2003; Hale et al. 2008) through species-specific interactions with multiple host proteins (Rajsbaum et al. 2012). Mutations in NS1 have been frequently observed during mouse adaptation of AIVs (Dankar et al. 2011; Zhang et al. 2011). When crossing the species barrier, HPAIV H5N1 could acquire the adaptive substitution M16I in NEP to escape restricted viral genome replication in human cells (Mänz et al. 2012; Reuther et al. 2014).

\section{Host Factors That Contribute to Severe Clinical Symptoms in Infected People}

Several studies have explored the host factors that contribute to the severe clinical symptoms caused by AIV infections, including cytokine storms, preexisting immunity, age biases in exposure to infected poultry (Cowling et al. 2013a; Rivers et al. 2013), and host genes. However, none of these studies can fully explain the patterns of severe disease and mortality. A recent study revealed that childhood HA imprinting could provide profound, lifelong protection against severe infection and death caused by H5N1 and H7N9 viruses (Gostic et al. 2016). This study highlighted the contribution of antigenic imprinting to the severity of clinical symptoms. Nevertheless, we still have a long way to go before we fully understand the complex interplay between the pathogen and the host.

\section{The Cytokine Storm}

One hallmark of human HPAI H5 infections is a rapid and robust cytokine response, often referred to as a "cytokine storm" or hypercytoki- nemia. This buildup of cytokines causes an inflammatory environment at the site of infection, leading to immune cell infiltration (de Jong et al. 2006; Zhou et al. 2013; Wang et al. 2014b; Guo et al. 2015). Following infection with HPAI $\mathrm{H} 5 \mathrm{~N} 1$ viruses in animal models, including chickens, ferrets, and rhesus macaques, increased expression of specific pro-inflammatory cytokines, particularly interleukin (IL)-6 and IL-8, was observed, suggesting that IL- 6 and IL-8 may be key regulators leading to worsened pathology of viruses. Upon human infections with $\mathrm{H} 5 \mathrm{~N} 1$ viruses, a similarly robust cytokine response occurs with the up-regulation of IL-6, IL-10, and tumor necrosis factor (TNF)- $\alpha$. The levels of IP10, MIG, MCP-1, IL-6, IL-8, and IFN- $\alpha$ in sera from $\mathrm{H} 7 \mathrm{~N} 9$ virus-infected patients were significantly higher than those of healthy people (Zhou et al. 2013). Therefore, the "cytokine storm" caused by disorder of the natural immune response may be an important contributor to severe infections. Infections of chickens with the recently emerged HPAI H5N6 viruses (which have caused several human fatalities), results in a very distinct immune response relative to other H5N6 strains by inducing much higher levels of IL-6, IL-8, and other pro-inflammatory mediators such as TNF- $\alpha$ (Gao et al. 2017).

\section{Tissue Tropism}

Unlike seasonal influenza virus infections, which are often confined to the respiratory system, H5N1 AIV infection can cause viremia (Likos et al. 2007). H5N1 viruses can be detected and isolated in the plasma of the patients, and the virus can spread to all organs and tissues including the brain (Chutinimitkul et al. 2006; Likos et al. 2007; Gao et al. 2010). Additionally, viruses can also be detected in human fecal specimens (Gao et al. 2010). Limited studies have shown that systemic spread of the virus may exacerbate disease progression, with megatrophils potentially playing an important role (Gao et al. 2010; Schrauwen et al. 2012). Similar to HPAI H5N1 viruses, LPAI H7N9 viruses can infect type II alveolar epithelial cells and replicate in them effectively, which may further damage lung function (van Riel et al. 2013; Zhou 
D. Wang et al.

Table 2. Host genes associated with severe outcomes of H7N9 infections in humans

\begin{tabular}{llcl}
\hline Host gene & \multicolumn{1}{c}{ SNP } & Animal studies & \multicolumn{1}{c}{ Reference(s) } \\
\hline IFITM 3 & rs12252/rs34481144 & + & Wang et al. 2014b; Lee et al. 2017; Pan et al. 2017 \\
TMRPSS2 & rs2070788/rs383510 & + & Cheng et al. 2015 \\
LGALS1 & rs4820294/rs2899292 & + & Chen et al. 2015 \\
& haplotype GG & & \\
CD55 & rs2564978 & - & Lee et al. 2017 \\
\hline
\end{tabular}

(SNP) Single-nucleotide polymorphism, (+) validated in mouse models, (-) not validated in mouse models.

et al. 2013). Compared with LPAI H7N9 viruses, which mainly replicate in respiratory tissues, HPAI H7N9 viruses can spread systemically in infected ferrets (Zhu et al. 2015; Imai et al. 2017; Shi et al. 2017). These latter viruses could infect and replicate efficiently in brain tissue, thus causing the death of the ferrets.

\section{Host Genes}

Interferon-induced transmembrane protein 3 (IFITM3) genetic variants influence the severity of clinical symptoms. The effects of genetic variation in the IFITM3 gene on influenza disease were first identified during the $2009 \mathrm{H} 1 \mathrm{~N} 1$ pandemic (Everitt et al. 2012; Zhang et al. 2013d). This genetic variation was also associated with severe disease in some H7N9 patients (Wang et al. 2014b; Lee et al. 2017; Pan et al. 2017). Among H7N9 patients, the IFITM3 C/C genotype was associated with more severe clinical symptoms than the $\mathrm{C} / \mathrm{T}$ and $\mathrm{T} / \mathrm{T}$ genotypes (Wang et al., 2014b). Other host factors, including TMPRSS2, LGALS1, and CD55, were also reported to be associated with poor outcomes of H7N9 infections (Table 2) (Chen et al. 2015; Cheng et al. 2015; Lee et al. 2017).

\section{CONCLUDING REMARKS}

Influenza is an acute respiratory disease caused by influenza viruses. It can cause serious public health concerns such as epidemics, zoonotic infections, and pandemics. Influenza pandemics are unpredictable but recurring events that can have profound consequences on human health and economic well-being worldwide. Risk assessment tools and pandemic preparedness plans are essential to help mitigate the impact of a pandemic. Recently, the United States Center for Disease Control and the World Health Organization have developed different risk assessment tools that can be used to assess the pandemic risk of influenza viruses with pandemic potential. Since 1997, AIVs of the H5 subtype have been considered zoonotic viruses with pandemic potential; fortunately, no such event has occurred to date. However, we cannot exclude the possibility of AIV causing pandemics in future. These viruses may acquire the ability to transmit efficiently among humans, through mutations, reassortments, or both. Under the "One Health" approach, the global surveillance system for zoonotic influenza viruses should be further expanded in animals and humans, and epidemiologic investigations as well as virologic and pathogenesis research should be reinforced to provide essential scientific evidence for the risk assessment and early warning of a potential pandemic. Universal influenza vaccines and novel antiviral drugs may provide better protection against future pandemics.

\section{ACKNOWLEDGMENTS}

This study was supported by the National Nature Science Foundation of China (8196112 8002), the National Key Research and Development Program of China (2016YFD0500208), and the National Mega-projects for Infectious Diseases (2017ZX10104001002002).

This article has been made freely available online courtesy of TAUNS Laboratories.

\section{REFERENCES}

Alexander DJ, Brown IH. 2009. History of highly pathogenic avian influenza. Rev Sci Tech 28: 19-38. doi:10.20506/rst .28 .1 .1856 
Arzey GG, Kirkland PD, Arzey KE, Frost M, Maywood P, Conaty S, Hurt AC, Deng YM, Iannello P, Barr I, et al. 2012. Influenza virus A (H10N7) in chickens and poultry abattoir workers, Australia. Emerg Infect Dis 18: 814-816. doi:10.3201/eid1805.111852

Bender C, Hall H, Huang J, Klimov A, Cox N, Hay A, Gregory V, Cameron K, Lim W, Subbarao K. 1999. Characterization of the surface proteins of influenza A (H5N1) viruses isolated from humans in 1997-1998. Virology 254: 115-123. doi:10.1006/viro.1998.9529

Bosch FX, Garten W, Klenk HD, Rott R. 1981. Proteolytic cleavage of influenza virus hemagglutinins: primary structure of the connecting peptide between HAl and HA2 determines proteolytic cleavability and pathogenicity of avian influenza viruses. Virology 113: 725-735. doi:10.1016/0042-6822(81)90201-4

Chan LL, Bui CT, Mok CK, Ng MM, Nicholls JM, Peiris JS, Chan MC, Chan RW. 2016. Evaluation of the human adaptation of influenza $\mathrm{A} / \mathrm{H} 7 \mathrm{~N} 9$ virus in $\mathrm{PB} 2$ protein using human and swine respiratory tract explant cultures. Sci Rep 6: 35401. doi:10.1038/srep35401

Chandrasekaran A, Srinivasan A, Raman R, Viswanathan K, Raguram S, Tumpey TM, Sasisekharan V, Sasisekharan R. 2008. Glycan topology determines human adaptation of avian H5N1 virus hemagglutinin. Nat Biotechnol 26: 107-113. doi:10.1038/nbt1375

Chen H, Bright RA, Subbarao K, Smith C, Cox NJ, Katz JM, Matsuoka Y. 2007. Polygenic virulence factors involved in pathogenesis of 1997 Hong Kong H5N1 influenza viruses in mice. Virus Res 128: 159-163. doi:10.1016/j.virusres .2007 .04 .017

Chen LM, Blixt O, Stevens J, Lipatov AS, Davis CT, Collins BE, Cox NJ, Paulson JC, Donis RO. 2012. In vitro evolution of H5N1 avian influenza virus toward human-type receptor specificity. Virology 422: 105-113. doi:10.1016/j .virol.2011.10.006

Chen H, Yuan H, Gao R, Zhang J, Wang D, Xiong Y, Fan G, Yang F, Li X, Zhou J, et al. 2014. Clinical and epidemiological characteristics of a fatal case of avian influenza A H10N8 virus infection: descriptive study. Lancet 383: 714-721. doi:10.1016/S0140-6736(14)60111-2

Chen Y, Zhou J, Cheng Z, Yang S, Chu H, Fan Y, Li C, Wong BH, Zheng S, Zhu Y, et al. 2015. Functional variants regulating LGALS1 (Galectin 1) expression affect human susceptibility to influenza A(H7N9). Sci Rep 5: 8517. doi:10.1038/srep08517

Cheng Z, Zhou J, To KK, Chu H, Li C, Wang D, Yang D, Zheng S, Hao K, Bosse Y, et al. 2015. Identification of TMPRSS2 as a susceptibility gene for severe 2009 pandemic $\mathrm{A}(\mathrm{H} 1 \mathrm{~N} 1)$ influenza and $\mathrm{A}(\mathrm{H} 7 \mathrm{~N} 9)$ influenza. J Infect Dis 212: 1214-1221. doi:10.1093/infdis/jiv246

Chutinimitkul S, Bhattarakosol P, Srisuratanon S, Eiamudomkan A, Kongsomboon K, Damrongwatanapokin S, Chaisingh A, Suwannakarn K, Chieochansin T, Theamboonlers A, et al. 2006. H5N1 influenza A virus and infected human plasma. Emerg Infect Dis 12: 1041-1043. doi:10.3201/eid1206.060227

Chutinimitkul S, van Riel D, Munster VJ, van den Brand JM, Rimmelzwaan GF, Kuiken T, Osterhaus AD, Fouchier RA, de Wit E. 2010. In vitro assessment of attachment pattern and replication efficiency of $\mathrm{H} 5 \mathrm{~N} 1$ influenza A viruses with altered receptor specificity. J Virol 84: 68256833. doi:10.1128/JVI.02737-09

Claas EC, Osterhaus AD, van Beek R, De Jong JC, Rimmelzwaan GF, Senne DA, Krauss S, Shortridge KF, Webster RG. 1998. Human influenza A H5N1 virus related to a highly pathogenic avian influenza virus. Lancet 351: 472 477. doi:10.1016/S0140-6736(97)11212-0

Connor RJ, Kawaoka Y, Webster RG, Paulson JC. 1994. Receptor specificity in human, avian, and equine $\mathrm{H} 2$ and $\mathrm{H} 3$ influenza virus isolates. Virology 205: 17-23. doi:10.1006/ viro.1994.1615

Cowling BJ, Freeman G, Wong JY, Wu P, Liao Q, Lau EH, Wu JT, Fielding R, Leung GM. 2013a. Preliminary inferences on the age-specific seriousness of human disease caused by avian influenza A(H7N9) infections in China, March to April 2013. Euro Surveill 18: 20475.

Cowling BJ, Jin L, Lau EH, Liao Q, Wu P, Jiang H, Tsang TK, Zheng J, Fang VJ, Chang Z, et al. 2013b. Comparative epidemiology of human infections with avian influenza A H7N9 and H5N1 viruses in China: a population-based study of laboratory-confirmed cases. Lancet 382: 129137. doi:10.1016/S0140-6736(13)61171-X

Cui L, Liu D, Shi W, Pan J, Qi X, Li X, Guo X, Zhou M, Li W, $\mathrm{Li}$ J, et al. 2014. Dynamic reassortments and genetic heterogeneity of the human-infecting influenza A (H7N9) virus. Nat Commun 5: 3142. doi:10.1038/ncomms4142

Dankar SK, Wang S, Ping J, Forbes NE, Keleta L, Li Y, Brown EG. 2011. Influenza A virus NS1 gene mutations F103L and M106I increase replication and virulence. Virol J 8: 13. doi:10.1186/1743-422X-8-13

de Jong MD, Simmons CP, Thanh TT, Hien VM, Smith GJ, Chau TN, Hoang DM, Chau NV, Khanh TH, Dong VC, et al. 2006. Fatal outcome of human influenza A (H5N1) is associated with high viral load and hypercytokinemia. Nat Med 12: 1203-1207. doi:10.1038/nm1477

Deng Y, Li C, Han J, Wen Y, Wang J, Hong W, Li X, Liu Z, Ye $\mathrm{Q}, \mathrm{Li}$ J, et al. 2017. Phylogenetic and genetic characterization of a 2017 clinical isolate of H7N9 virus in Guangzhou, China during the fifth epidemic wave. Sci China Life Sci 60: 1331-1339. doi:10.1007/s11427-017-9152-1

de Vries RP, Peng W, Grant OC, Thompson AJ, Zhu X, Bouwman KM, de la Pena ATT, van Breemen MJ, Ambepitiya Wickramasinghe IN, de Haan CAM, et al. 2017a. Three mutations switch H7N9 influenza to human-type receptor specificity. PLoS Pathog 13: e1006390. doi:10 .1371/journal.ppat.1006390

de Vries RP, Tzarum N, Peng W, Thompson AJ, Ambepitiya Wickramasinghe IN, de la Pena ATT, van Breemen MJ, Bouwman KM, Zhu X, McBride R, et al. 2017b. A single mutation in Taiwanese H6N1 influenza hemagglutinin switches binding to human-type receptors. EMBO Mol Med 9: 1314-1325. doi:10.15252/emmm.201707726

Donelan NR, Basler CF, García-Sastre A. 2003. A recombinant influenza A virus expressing an RNA-binding-defective NS1 protein induces high levels of $\beta$ interferon and is attenuated in mice. J Virol 77: 13257-13266. doi:10 $.1128 / J V I .77 .24 .13257-13266.2003$

Everitt AR, Clare S, Pertel T, John SP, Wash RS, Smith SE, Chin CR, Feeley EM, Sims JS, Adams DJ, et al. 2012. IFITM3 restricts the morbidity and mortality associated with influenza. Nature 484: 519-523. doi:10.1038/na ture10921 
D. Wang et al.

Fonville JM, Burke DF, Lewis NS, Katzelnick LC, Russell CA 2013. Quantifying the fitness advantage of polymerase substitutions in Influenza A/H7N9 viruses during adaptation to humans. PLoS ONE 8: e76047. doi:10.1371/jour nal.pone.0076047

Fouchier RA, Schneeberger PM, Rozendaal FW, Broekman JM, Kemink SA, Munster V, Kuiken T, Rimmelzwaan GF, Schutten M, Van Doornum GJ, et al. 2004. Avian influenza A virus (H7N7) associated with human conjunctivitis and a fatal case of acute respiratory distress syndrome. Proc Natl Acad Sci 101: 1356-1361. doi:10 $.1073 /$ pnas.0308352100

Gambaryan A, Tuzikov A, Pazynina G, Bovin N, Balish A, Klimov A. 2006. Evolution of the receptor binding phenotype of influenza A (H5) viruses. Virology 344: 432 438. doi:10.1016/j.virol.2005.08.035

Gao R, Dong L, Dong J, Wen L, Zhang Y, Yu H, Feng Z, Chen M, Tan Y, Mo Z, et al. 2010. A systematic molecular pathology study of a laboratory confirmed $\mathrm{H} 5 \mathrm{~N} 1$ human case. PLOS ONE 5: e13315. doi:10.1371/journal.pone .0013315

Gao HN, Lu HZ, Cao B, Du B, Shang H, Gan JH, Lu SH, Yang YD, Fang Q, Shen YZ, et al. 2013a. Clinical findings in 111 cases of influenza A (H7N9) virus infection. NEngl $J$ Med 368: 2277-2285. doi:10.1056/NEJMoa1305584

Gao R, Cao B, Hu Y, Feng Z, Wang D, Hu W, Chen J, Jie Z, Qiu H, Xu K, et al. 2013b. Human infection with a novel avian-origin influenza A (H7N9) virus. N Engl J Med 368: 1888-1897. doi:10.1056/NEJMoa1304459

Gao S, Kang Y, Yuan R, Ma H, Xiang B, Wang Z, Dai X, Wang F, Xiao J, Liao M, et al. 2017. Immune responses of chickens infected with wild bird-origin H5N6 avian influenza virus. Front Microbiol 8: 1081. doi:10.3389/fmicb .2017.01081

Garten W, Klenk HD. 1999. Understanding influenza virus pathogenicity. Trends Microbiol 7: 99-100. doi:10.1016/ S0966-842X(99)01460-2

Gostic KM, Ambrose M, Worobey M, Lloyd-Smith JO. 2016 Potent protection against $\mathrm{H} 5 \mathrm{~N} 1$ and $\mathrm{H} 7 \mathrm{~N} 9$ influenza via childhood hemagglutinin imprinting. Science 354: 722726. doi:10.1126/science.aag1322

Guo Y, Li J, Cheng X. 1999. [Discovery of men infected by avian influenza A (H9N2) virus]. Zhonghua Shi Yan He Lin Chuang Bing Du Xue Za Zhi 13: 105-108.

Guo J, Huang F, Liu J, Chen Y, Wang W, Cao B, Zou Z, Liu S, Pan J, Bao C, et al. 2015. The serum profile of hypercytokinemia factors identified in H7N9-infected patients can predict fatal outcomes. Sci Rep 5: 10942. doi:10.1038/ srep10942

Guo H, de Vries E, McBride R, Dekkers J, Peng W, Bouwman KM, Nycholat C, Verheije MH, Paulson JC, van Kuppeveld FJ, et al. 2017. Highly pathogenic influenza A(H5Nx) viruses with altered H5 receptor-binding specificity. Emerg Infect Dis 23: 220-231. doi:10.3201/eid2302 .161072

Hale BG, Randall RE, Ortin J, Jackson D. 2008. The multifunctional NS1 protein of influenza A viruses. J Gen Virol 89: 2359-2376. doi:10.1099/vir.0.2008/004606-0

Han J, Jin M, Zhang P, Liu J, Wang L, Wen D, Wu X, Liu G, Zou Y, Lv X, et al. 2013. Epidemiological link between exposure to poultry and all influenza $\mathrm{A}(\mathrm{H} 7 \mathrm{~N} 9)$ confirmed cases in Huzhou city, China, March to May 2013. Euro Surveill 18: 20481.

Harvey R, Martin AC, Zambon M, Barclay WS. 2004. Restrictions to the adaptation of influenza a virus $\mathrm{H} 5 \mathrm{hem}$ agglutinin to the human host. J Virol 78: 502-507. doi:10 1128/JVI.78.1.502-507.2004

Hatta M, Gao P, Halfmann P, Kawaoka Y. 2001. Molecular basis for high virulence of Hong Kong H5N1 influenza A viruses. Science 293: 1840-1842. doi:10.1126/science .1062882

Herfst S, Schrauwen EJ, Linster M, Chutinimitkul S, de Wit E, Munster VJ, Sorrell EM, Bestebroer TM, Burke DF Smith DJ, et al. 2012. Airborne transmission of influenza A/H5N1 virus between ferrets. Science 336: 1534-1541. doi:10.1126/science.1213362

Herfst S, Imai M, Kawaoka Y, Fouchier RA. 2014. Avian Influenza virus transmission to mammals. Curr Top Microbiol Immunol 385: 137-155.

Hirst M, Astell CR, Griffith M, Coughlin SM, Moksa M, Zeng T, Smailus DE, Holt RA, Jones S, Marra MA, et al. 2004. Novel avian influenza H7N3 strain outbreak, British Columbia. Emerg Infect Dis 10: 2192-2195. doi:10 3201/eid1012.040743

Imai M, Watanabe T, Hatta M, Das SC, Ozawa M, Shinya K, Zhong G, Hanson A, Katsura H, Watanabe S, et al. 2012. Experimental adaptation of an influenza H5 HA confers respiratory droplet transmission to a reassortant $\mathrm{H} 5 \mathrm{HA} /$ H1N1 virus in ferrets. Nature 486: 420-428. doi:10.1038/ nature10831

Imai M, Watanabe T, Kiso M, Nakajima N, Yamayoshi $\mathrm{S}$, Iwatsuki-Horimoto K, Hatta M, Yamada S, Ito M, SakaiTagawa Y, et al. 2017. A highly pathogenic avian H7N9 influenza virus isolated from a human is lethal in some ferrets infected via respiratory droplets. Cell Host Microbe 22: 615-626 e8. doi:10.1016/j.chom.2017.09.008

Ke C, Mok CKP, Zhu W, Zhou H, He J, Guan W, Wu J, Song W, Wang D, Liu J, et al. 2017. Human infection with highly pathogenic avian influenza $\mathrm{A}(\mathrm{H} 7 \mathrm{~N} 9)$ virus, China. Emerg Infect Dis 23: 1332-1340. doi:10.3201/eid2308 .170600

Klenk HD, Garten W. 1994. Host cell proteases controlling virus pathogenicity. Trends Microbiol 2: 39-43. doi:10 .1016/0966-842X(94)90123-6

Koopmans M, Wilbrink B, Conyn M, Natrop G, van der Nat $\mathrm{H}$, Vennema H, Meijer A, van Steenbergen J, Fouchier R, Osterhaus A, et al. 2004. Transmission of H7N7 avian influenza A virus to human beings during a large outbreak in commercial poultry farms in the Netherlands. Lancet 363: 587-593. doi:10.1016/S0140-6736(04)15589-X

Lam TT, Zhou B, Wang J, Chai Y, Shen Y, Chen X, Ma C, Hong W, Chen Y, Zhang Y, et al. 2015. Dissemination, divergence and establishment of H7N9 influenza viruses in China. Nature 522: 102-105. doi:10.1038/nature14348

Lee N, Cao B, Ke C, Lu H, Hu Y, Tam CHT, Ma RCW, Guan $\mathrm{D}$, Zhu Z, Li H, et al. 2017. IFITM3, TLR3, and CD55 gene SNPs and cumulative genetic risks for severe outcomes in Chinese patients with H7N9/H1N1pdm09 influenza. J Infect Dis 216: 97-104. doi:10.1093/infdis/jix235

Li X, Tian B, Jianfang Z, Yongkun C, Xiaodan L, Wenfei Z, Yan L, Jing T, Junfeng G, Tao C, et al. 2017. A comprehensive retrospective study of the seroprevalence of H9N2 avian influenza viruses in occupationally exposed popu- 
lations in China. PLoS ONE 12: e0178328. doi:10.1371/ journal.pone.0178328

Likos AM, Kelvin DJ, Cameron CM, Rowe T, Kuehnert MJ, Norris PJ, National Heart Lung Blood Institute Retrovirus Epidemiology Donor Study-II (REDS-II) 2007. Influenza viremia and the potential for blood-borne transmission. Transfusion 47: 1080-1088. doi:10.1111/j.1537-2995 .2007.01264.x

Linster M, van Boheemen S, de Graaf M, Schrauwen EJA, Lexmond P, Mänz B, Bestebroer TM, Baumann J, van Riel D, Rimmelzwaan GF, et al. 2014. Identification, characterization, and natural selection of mutations driving airborne transmission of $\mathrm{A} / \mathrm{H} 5 \mathrm{~N} 1$ virus. Cell 157: 329-339. doi:10.1016/j.cell.2014.02.040

Liu D, Shi W, Shi Y, Wang D, Xiao H, Li W, Bi Y, Wu Y, Li X, Yan J, et al. 2013. Origin and diversity of novel avian influenza A H7N9 viruses causing human infection: phylogenetic, structural, and coalescent analyses. Lancet 381: 1926-1932. doi:10.1016/S0140-6736(13)60938-1

Lu CY, Lu JH, Chen WQ, Jiang LF, Tan BY, Ling WH, Zheng BJ, Sui HY. 2008. Potential infections of H5N1 and H9N2 avian influenza do exist in Guangdong populations of China. Chin Med J (Engl) 121: 2050-2053. doi:10.1097/ 00029330-200810020-00020

Lu S, Zheng Y, Li T, Hu Y, Liu X, Xi X, Chen Q, Wang Q, Cao Y, Wang Y, et al. 2013. Clinical findings for early human cases of influenza A(H7N9) virus infection, Shanghai, China. Emerg Infect Dis 19: 1142-1146.

Maines TR, Lu XH, Erb SM, Edwards L, Guarner J, Greer PW, Nguyen DC, Szretter KJ, Chen LM, Thawatsupha P, et al. 2005. Avian influenza (H5N1) viruses isolated from humans in Asia in 2004 exhibit increased virulence in mammals. J Virol 79: 11788-11800. doi:10.1128/JVI.79 $.18 .11788-11800.2005$

Manz B, Matrosovich M, Bovin N, Schwemmle M. 2010. A polymorphism in the hemagglutinin of the human isolate of a highly pathogenic H5N1 influenza virus determines organ tropism in mice. J Virol 84: 8316-8321. doi:10 $.1128 / J V I .00850-10$

Mänz B, Brunotte L, Reuther P, Schwemmle M. 2012. Adaptive mutations in NEP compensate for defective H5N1 RNA replication in cultured human cells. Nat Commun 3: 802 . doi: $10.1038 /$ ncomms 1804

Manz B, Schwemmle M, Brunotte L. 2013. Adaptation of avian influenza $A$ virus polymerase in mammals to overcome the host species barrier. J Virol 87: 7200-7209. doi:10.1128/JVI.00980-13

Mok CK, Lee HH, Lestra M, Nicholls JM, Chan MC, Sia SF, Zhu H, Poon LL, Guan Y, Peiris JS. 2014. Amino acid substitutions in polymerase basic protein 2 gene contribute to the pathogenicity of the novel A/H7N9 influenza virus in mammalian hosts. J Virol 88: 3568-3576. doi:10 $.1128 / J V I .02740-13$

Munster VJ, de Wit E, van Riel D, Beyer WE, Rimmelzwaan GF, Osterhaus AD, Kuiken T, Fouchier RA. 2007. The molecular basis of the pathogenicity of the Dutch highly pathogenic human influenza A H7N7 viruses. J Infect Dis 196: $258-265$. doi: $10.1086 / 518792$

Nidom CA, Takano R, Yamada S, Sakai-Tagawa Y, Daulay S, Aswadi D, Suzuki T, Suzuki Y, Shinya K, Iwatsuki-Horimoto $\mathrm{K}$, et al. 2010. Influenza A (H5N1) viruses from pigs, Indonesia. Emerg Infect Dis 16: 1515-1523. doi:10 $.3201 /$ eid1610.100508

Olsen SJ, Ungchusak K, Sovann L, Uyeki TM, Dowell SF, Cox NJ, Aldis W, Chunsuttiwat S. 2005. Family clustering of avian influenza A (H5N1). Emerg Infect Dis 11: 17991801. doi:10.3201/eid1111.050646

Organization PAH. 2004. Avian influenza virus A (H10N7) circulating among humans in Egypt. https://www.paho .org/hq/index.php?option=com_docman\&view=downlo ad\&alias $=8363$-avian-influenza-virus-a-h10n7-circulatin g-among-humans-egypt-vol-2-no-18-7-may-2004-363\& category_slug=see-influenza-reports-by-year-4302\&Item $\mathrm{id}=270$ \&lang $=\mathrm{en}$

Pan M, Gao R, Lv Q, Huang S, Zhou Z, Yang L, Li X, Zhao X, Zou X, Tong W, et al. 2016. Human infection with a novel, highly pathogenic avian influenza A (H5N6) virus: virological and clinical findings. $J$ Infect 72: 52-59. doi:10 $.1016 /$ j.jinf.2015.06.009

Pan Y, Yang P, Dong T, Zhang Y, Shi W, Peng X, Cui S, Zhang D, Lu G, Liu Y, et al. 2017. IFITM3 Rs12252-C variant increases potential risk for severe influenza virus infection in Chinese population. Front Cell Infect Microbiol 7: 294. doi:10.3389/fcimb.2017.00294

Pawar SD, Tandale BV, Raut CG, Parkhi SS, Barde TD, Gurav YK, Kode SS, Mishra AC. 2012. Avian influenza H9N2 seroprevalence among poultry workers in Pune, India, 2010. PLoS ONE 7: e36374. doi:10.1371/journal .pone.0036374

Peiris M, Yuen KY, Leung CW, Chan KH, Ip PL, Lai RW, Orr WK, Shortridge KF. 1999. Human infection with influenza H9N2. Lancet 354: 916-917. doi:10.1016/S0140-6736 (99)03311-5

Peiris JS, Yu WC, Leung CW, Cheung CY, Ng WF, Nicholls JM, Ng TK, Chan KH, Lai ST, Lim WL, et al. 2004. Reemergence of fatal human influenza A subtype H5N1 disease. Lancet 363: 617-619. doi:10.1016/S0140-6736 (04) 15595-5

Peiris JS, de Jong MD, Guan Y. 2007. Avian influenza virus (H5N1): a threat to human health. Clin Microbiol Rev 20: 243-267. doi:10.1128/CMR.00037-06

Qi L, Davis AS, Jagger BW, Schwartzman LM, Dunham EJ, Kash JC, Taubenberger JK. 2012. Analysis by single-gene reassortment demonstrates that the 1918 influenza virus is functionally compatible with a low-pathogenicity avian influenza virus in mice. J Virol 86: 9211-9220. doi:10 $.1128 /$ JVI.00887-12

Qin Y, Horby PW, Tsang TK, Chen E, Gao L, Ou J, Nguyen TH, Duong TN, Gasimov V, Feng L, et al. 2015. Differences in the epidemiology of human cases of avian influenza $\mathrm{A}(\mathrm{H} 7 \mathrm{~N} 9)$ and $\mathrm{A}(\mathrm{H} 5 \mathrm{~N} 1)$ viruses infection. Clin Infect Dis 61: 563-571. doi:10.1093/cid/civ345

Qu Z, Ma S, Kong H, Deng G, Shi J, Liu L, Suzuki Y, Chen H. 2017. Identification of a key amino acid in hemagglutinin that increases human-type receptor binding and transmission of an $\mathrm{H} 6 \mathrm{~N} 2$ avian influenza virus. Microbes Infect 19: 655-660. doi:10.1016/j.micinf.2017.09.008

Rajsbaum R, Albrecht RA, Wang MK, Maharaj NP, Versteeg GA, Nistal-Villan E, García-Sastre A, Gack MU. 2012. Species-specific inhibition of RIG-I ubiquitination and IFN induction by the influenza A virus NS1 protein. PLoS Pathog 8: e1003059. doi:10.1371/journal.ppat .1003059 
D. Wang et al.

Reuther P, Giese S, Gotz V, Kilb N, Manz B, Brunotte L, Schwemmle M. 2014. Adaptive mutations in the nuclear export protein of human-derived $\mathrm{H} 5 \mathrm{~N} 1$ strains facilitate a polymerase activity-enhancing conformation. J Virol 88: 263-271. doi:10.1128/JVI.01495-13

Richard M, Schrauwen EJ, de Graaf M, Bestebroer TM, Spronken MI, van Boheemen S, de Meulder D, Lexmond P, Linster M, Herfst S, et al. 2013. Limited airborne transmission of H7N9 influenza A virus between ferrets. $\mathrm{Na}$ ture 501: 560-563. doi:10.1038/nature12476

Rivers C, Lum K, Lewis B, Eubank S. 2013. Estimating human cases of avian influenza A(H7N9) from poultry exposure. PLoS Curr 5. pii: ecurrents.outbreaks.264e 737b489bef383fbcbaba260daf928. doi:10.1371/currents .outbreaks.264e737b489bef383fbcbaba60daf928

Russell CA, Fonville JM, Brown AE, Burke DF, Smith DL, James SL, Herfst S, van Boheemen S, Linster M, Schrauwen EJ, et al. 2012. The potential for respiratory droplettransmissible $\mathrm{A} / \mathrm{H} 5 \mathrm{~N} 1$ influenza virus to evolve in a mammalian host. Science 336: 1541-1547. doi:10.1126/ science. 1222526

Schrauwen EJ, Herfst S, Leijten LM, van Run P, Bestebroer TM, Linster M, Bodewes R, Kreijtz JH, Rimmelzwaan GF Osterhaus AD, et al. 2012. The multibasic cleavage site in $\mathrm{H} 5 \mathrm{~N} 1$ virus is critical for systemic spread along the olfactory and hematogenous routes in ferrets. J Virol 86: 39753984. doi:10.1128/JVI.06828-11

Shi Y, Zhang W, Wang F, Qi J, Wu Y, Song H, Gao F, Bi Y, Zhang Y, Fan Z, et al. 2013a. Structures and receptor binding of hemagglutinins from human-infecting H7N9 influenza viruses. Science 342: 243-247. doi:10.1126/sci ence. 1242917

Shi J, Deng G, Liu P, Zhou J, Guan L, Li W, Li X, Guo J, Wang G, Fan J, et al. 2013b. Isolation and characterization of H7N9 viruses from live poultry markets-implication of the source of current H7N9 infection in humans. Chinese Sci Bull 58: 1857-1863. doi: 10.1007/s11434-013-5873-4.

Shi J, Deng G, Kong H, Gu C, Ma S, Yin X, Zeng X, Cui P, Chen Y, Yang H, et al. 2017. H7N9 virulent mutants detected in chickens in China pose an increased threat to humans. Cell Res 27: 1409-1421.

Shinde PV, Koratkar SS, Pawar SD, Kale SD, Rawankar AS, Mishra AC. 2012. Serologic evidence of avian influenza H9N2 and paramyxovirus type 1 infection in emus (Dromaius novaehollandiae) in India. Avian Dis 56: 257-260. doi:10.1637/9878-080511-Case.1

Shinya K, Ebina M, Yamada S, Ono M, Kasai N, Kawaoka Y. 2006. Avian flu: influenza virus receptors in the human airway. Nature 440: 435-436. doi:10.1038/440435a

Shinya K, Makino A, Hatta M, Watanabe S, Kim JH, Kawaoka Y. 2010. A mutation in $\mathrm{H} 5$ haemagglutinin that conferred human receptor recognition is not maintained stably during duck passage. J Gen Virol 91: 1461-1463. doi:10.1099/vir.0.018572-0

Shinya K, Makino A, Hatta M, Watanabe S, Kim JH, Hatta Y, Gao P, Ozawa M, Le QM, Kawaoka Y. 2011. Subclinical brain injury caused by $\mathrm{H} 5 \mathrm{~N} 1$ influenza virus infection. $J$ Virol 85: 5202-5207. doi:10.1128/JVI.00239-11

Shortridge KF. 1992. Pandemic influenza: a zoonosis? Semin Respir Infect 7: 11-25.

Shu Y, Yu H, Li D. 2006. Lethal avian influenza A (H5N1) infection in a pregnant woman in Anhui Province, China.
$N$ Engl J Med 354: 1421-1422. doi:10.1056/NEJMc 053524

Srinivasan K, Raman R, Jayaraman A, Viswanathan K, Sasisekharan R. 2013. Quantitative description of glycan-receptor binding of influenza A virus $\mathrm{H} 7$ hemagglutinin. PLoS One 8: e49597. doi:10.1371/journal.pone.0049597

Stevens J, Blixt O, Tumpey TM, Taubenberger JK, Paulson JC, Wilson IA. 2006. Structure and receptor specificity of the hemagglutinin from an $\mathrm{H} 5 \mathrm{~N} 1$ influenza virus. Science 312: 404-410. doi:10.1126/science. 1124513

Subbarao K, Klimov A, Katz J, Regnery H, Lim W, Hall H, Perdue M, Swayne D, Bender C, Huang J, et al. 1998. Characterization of an avian influenza A (H5N1) virus isolated from a child with a fatal respiratory illness. Science 279: 393-396. doi:10.1126/science.279.5349.393

Suguitan AL Jr, Matsuoka Y, Lau YF, Santos CP, Vogel L, Cheng LI, Orandle M, Subbarao K. 2012. The multibasic cleavage site of the hemagglutinin of highly pathogenic A/ Vietnam/1203/2004 (H5N1) avian influenza virus acts as a virulence factor in a host-specific manner in mammals. J Virol 86: 2706-2714. doi:10.1128/JVI.05546-11

Tanaka H, Park CH, Ninomiya A, Ozaki H, Takada A, Umemura T, Kida H. 2003. Neurotropism of the 1997 Hong Kong H5N1 influenza virus in mice. Vet Microbiol 95: 113. doi:10.1016/S0378-1135(03)00132-9

Tharakaraman K, Jayaraman A, Raman R, Viswanathan K, Stebbins NW, Johnson D, Shriver Z, Sasisekharan V, Sasisekharan R. 2013. Glycan receptor binding of the influenza A virus H7N9 hemagglutinin. Cell 153: 1486-1493. doi:10.1016/j.cell.2013.05.034

To KK, Chan JF, Chen H, Li L, Yuen KY. 2013. The emergence of influenza A H7N9 in human beings 16 years after influenza A H5N1: a tale of two cities. Lancet Infect Dis 13: 809-821. doi:10.1016/S1473-3099(13)70167-1

Tong XC, Weng SS, Xue F, Wu X, Xu TM, Zhang WH. 2018. First human infection by a novel avian influenza $A$ (H7N4) virus. J Infect 77: 249-257. doi:10.1016/j.jinf .2018.06.002

Tweed SA, Skowronski DM, David ST, Larder A, Petric M, Lees W, Li Y, Katz J, Krajden M, Tellier R, et al. 2004 Human illness from avian influenza H7N3, British Columbia. Emerg Infect Dis 10: 2196-2199. doi:10.3201/ eid1012.040961

Uyeki TM. 2009. Human infection with highly pathogenic avian influenza A (H5N1) virus: review of clinical issues. Clin Infect Dis 49: 279-290. doi:10.1086/600035

van Kolfschooten F. 2003. Dutch veterinarian becomes first victim of avian influenza. Lancet 361: 1444. doi:10.1016/ S0140-6736(03)13156-X

van Riel D, Leijten LM, de Graaf M, Siegers JY, Short KR, Spronken MI, Schrauwen EJ, Fouchier RA, Osterhaus AD, Kuiken T. 2013. Novel avian-origin influenza A (H7N9) virus attaches to epithelium in both upper and lower respiratory tract of humans. Am J Pathol 183: 1137 1143. doi:10.1016/j.ajpath.2013.06.011

Wan H, Sorrell EM, Song H, Hossain MJ, Ramirez-Nieto G, Monne I, Stevens J, Cattoli G, Capua I, Chen LM, et al. 2008. Replication and transmission of H9N2 influenza viruses in ferrets: evaluation of pandemic potential. PLoS ONE 3: e2923. doi:10.1371/journal.pone.0002923

Wan XF, Dong L, Lan Y, Long LP, Xu C, Zou S, Li Z, Wen L, Cai Z, Wang W, et al. 2011. Indications that live poultry 
markets are a major source of human H5N1 influenza virus infection in China. J Virol 85: 13432-13438. doi:10.1128/JVI.05266-11

Wang W, Lu B, Zhou H, Suguitan AL Jr, Cheng X, Subbarao K, Kemble G, Jin H. 2010. Glycosylation at $158 \mathrm{~N}$ of the hemagglutinin protein and receptor binding specificity synergistically affect the antigenicity and immunogenicity of a live attenuated H5N1 A/Vietnam/1203/2004 vaccine virus in ferrets. J Virol 84: 6570-6577. doi:10.1128/JVI .00221-10

Wang D, Yang L, Gao R, Zhang X, Tan Y, Wu A, Zhu W, Zhou J, Zou S, Li X, et al. 2014a. Genetic tuning of the novel avian influenza $\mathrm{A}(\mathrm{H} 7 \mathrm{~N} 9)$ virus during interspecies transmission, China, 2013. Euro Surveill 19: 20836. doi:10 .2807/1560-7917.ES2014.19.25.20836

Wang Z, Zhang A, Wan Y, Liu X, Qiu C, Xi X, Ren Y, Wang J, Dong Y, Bao M, et al. 2014b. Early hypercytokinemia is associated with interferon-induced transmembrane protein-3 dysfunction and predictive of fatal H7N9 infection. Proc Natl Acad Sci 111: 769-774. doi:10.1073/pnas .1321748111

Wang D, Yang L, Zhu W, Zhang Y, Zou S, Bo H, Gao R, Dong J, Huang W, Guo J, et al. 2016. Two outbreak sources of influenza A (H7N9) viruses have been established in China. J Virol 90: 5561-5573. doi:10.1128/JVI.03173-15

Wang X, Jiang H, Wu P, Uyeki TM, Feng L, Lai S, Wang L, Huo X, Xu K, Chen E, et al. 2017. Epidemiology of avian influenza A H7N9 virus in human beings across five epidemics in mainland China, 2013-17: an epidemiological study of laboratory-confirmed case series. Lancet Infect Dis 17: 822-832. doi:10.1016/S1473-3099(17)30323-7

Watanabe Y, Ibrahim MS, Ellakany HF, Kawashita N, Mizuike R, Hiramatsu H, Sriwilaijaroen N, Takagi T, Suzuki Y, Ikuta K. 2011. Acquisition of human-type receptor binding specificity by new H5N1 influenza virus sublineages during their emergence in birds in Egypt. PLoS Pathog 7: e1002068. doi:10.1371/journal.ppat.1002068

Watanabe T, Kiso M, Fukuyama S, Nakajima N, Imai M, Yamada S, Murakami S, Yamayoshi S, Iwatsuki-Horimoto K, Sakoda Y, et al. 2013. Characterization of H7N9 influenza A viruses isolated from humans. Nature 501: 551-555. doi:10.1038/nature12392

Webster RG, Rott R. 1987. Influenza virus A pathogenicity: the pivotal role of hemagglutinin. Cell 50: 665-666. doi:10 .1016/0092-8674(87)90321-7

Wei SH, Yang JR, Wu HS, Chang MC, Lin JS, Lin CY, Liu YL, Lo YC, Yang CH, Chuang JH, et al. 2013. Human infection with avian influenza A H6N1 virus: an epidemiological analysis. Lancet Respir Med 1: 771-778. doi:10.1016/ S2213-2600(13)70221-2

Woo JT, Park BK. 2008. Seroprevalence of low pathogenic avian influenza (H9N2) and associated risk factors in the Gyeonggi-do of Korea during 2005-2006. J Vet Sci 9: 161168. doi:10.4142/jvs.2008.9.2.161

Wu A, Su C, Wang D, Peng Y, Liu M, Hua S, Li T, Gao GF, Tang H, Chen J, et al. 2013. Sequential reassortments underlie diverse influenza H7N9 genotypes in China. Cell Host Microbe 14: 446-452. doi:10.1016/j.chom .2013 .09 .001

Xiong X, Martin SR, Haire LF, Wharton SA, Daniels RS, Bennett MS, McCauley JW, Collins PJ, Walker PA, Skehel JJ, et al. 2013. Receptor binding by an H7N9 influenza virus from humans. Nature 499: 496-499. doi:10.1038/ nature 12372

Xu C, Hu WB, Xu K, He YX, Wang TY, Chen Z, Li TX, Liu JH, Buchy P, Sun B. 2012. Amino acids 473V and 598P of $\mathrm{PB} 1$ from an avian-origin influenza A virus contribute to polymerase activity, especially in mammalian cells. J Gen Virol 93: 531-540. doi:10.1099/vir.0.036434-0

Yamada S, Suzuki Y, Suzuki T, Le MQ, Nidom CA, SakaiTagawa Y, Muramoto Y, Ito M, Kiso M, Horimoto T, et al. 2006. Haemagglutinin mutations responsible for the binding of H5N1 influenza A viruses to human-type receptors. Nature 444: 378-382. doi:10.1038/nature05264

Yang JR, Liu MT. 2017. Human infection caused by an avian influenza A (H7N9) virus with a polybasic cleavage site in Taiwan, 2017. J Formos Med Assoc 116: 210-212. doi:10 $.1016 /$ j.jfma.2017.02.011

Yang H, Chen LM, Carney PJ, Donis RO, Stevens J. 2010. Structures of receptor complexes of a North American H7N2 influenza hemagglutinin with a loop deletion in the receptor binding site. PLoS Pathog 6: 1001081. doi:10.1371/journal.ppat.1001081

Yang L, Zhu W, Li X, Bo H, Zhang Y, Zou S, Gao R, Dong J, Zhao X, Chen W, et al. 2016. Genesis and dissemination of highly pathogenic $\mathrm{H} 5 \mathrm{~N} 6$ avian influenza viruses. J Virol 91: e02199-02116.

Yang L, Zhu W, Li X, Chen M, Wu J, Yu P, Qi S, Huang Y, Shi W, Dong J, et al. 2017. Genesis and spread of newly emerged highly pathogenic H7N9 avian viruses in mainland China. J Virol 91: e01277-01217.

Yu H, Cowling BJ, Feng L, Lau EH, Liao Q, Tsang TK, Peng Z, Wu P, Liu F, Fang VJ, et al. 2013a. Human infection with avian influenza A H7N9 virus: an assessment of clinical severity. Lancet 382: 138-145. doi:10.1016/ S0140-6736(13)61207-6

Yu L, Wang Z, Chen Y, Ding W, Jia H, Chan JF, To KK, Chen $\mathrm{H}$, Yang Y, Liang W, et al. 2013b. Clinical, virological, and histopathological manifestations of fatal human infections by avian influenza $\mathrm{A}(\mathrm{H} 7 \mathrm{~N} 9)$ virus. Clin Infect Dis 57: 1449-1457. doi:10.1093/cid/cit541

Yuen KY, Chan PK, Peiris M, Tsang DN, Que TL, Shortridge KF, Cheung PT, To WK, Ho ET, Sung R, et al. 1998. Clinical features and rapid viral diagnosis of human disease associated with avian influenza A H5N1 virus. Lancet 351: 467-471. doi:10.1016/S0140-6736 (98)01182-9

Zhang Z, Hu S, Li Z, Wang X, Liu M, Guo Z, Li S, Xiao Y, Bi D, Jin H. 2011. Multiple amino acid substitutions involved in enhanced pathogenicity of LPAI H9N2 in mice. Infect Genet Evol 11: 1790-1797. doi:10.1016/j .meegid.2011.07.025

Zhang L, Zhang Z, Weng Z. 2013a. Rapid reassortment of internal genes in avian influenza A(H7N9) virus. Clin Infect Dis 57: 1059-1061. doi:10.1093/cid/cit414

Zhang Q, Shi J, Deng G, Guo J, Zeng X, He X, Kong H, Gu C, Li X, Liu J, et al. 2013b. H7N9 influenza viruses are transmissible in ferrets by respiratory droplet. Science 341: 410-414. doi:10.1126/science.1240532

Zhang Y, Zhang Q, Kong H, Jiang Y, Gao Y, Deng G, Shi J, Tian G, Liu L, Liu J, et al. 2013c. H5N1 hybrid viruses bearing 2009/H1N1 virus genes transmit in guinea pigs by respiratory droplet. Science 340: 1459-1463. doi:10 $.1126 /$ science. 1229455 
D. Wang et al.

Zhang YH, Zhao Y, Li N, Peng YC, Giannoulatou E, Jin RH, Yan HP, Wu H, Liu JH, Liu N, et al. 2013d. Interferoninduced transmembrane protein-3 genetic variant rs12252-C is associated with severe influenza in Chinese individuals. Nat Commun 4: 1418. doi:10.1038/ncom ms 2433

Zhang F, Bi Y, Wang J, Wong G, Shi W, Hu F, Yang Y, Yang L, Deng X, Jiang S, et al. 2017a. Human infections with recently-emerging highly pathogenic H7N9 avian influenza virus in China. J Infect 75: 71-75. doi:10.1016/j.jinf .2017.04.001

Zhang Y, Chen M, Huang Y, Zhu W, Yang L, Gao L, Li X, B F, Huang C, Kang N, et al. 2017b. Human infections with novel reassortant $\mathrm{H} 5 \mathrm{~N} 6$ avian influenza viruses in China. Emerg Microbes Infect 6: e50.

Zhou J, Wang D, Gao R, Zhao B, Song J, Qi X, Zhang Y, Shi Y, Yang L, Zhu W, et al. 2013. Biological features of novel avian influenza A (H7N9) virus. Nature 499: 500-503. doi:10.1038/nature12379

Zhou P, Zhu W, Gu H, Fu X, Wang L, Zheng Y, He S, Ke C Wang H, Yuan Z, et al. 2014. Avian influenza H9N2 seroprevalence among swine farm residents in China. $J$ Med Virol 86: 597-600. doi:10.1002/jmv.23869

Zhu W, Shu Y. 2015. Genetic tuning of avian influenza A (H7N9) virus promotes viral fitness within different species. Microbes Infect 17: 118-122. doi:10.1016/j.micinf .2014 .11 .010
Zhu H, Wang D, Kelvin DJ, Li L, Zheng Z, Yoon SW, Wong SS, Farooqui A, Wang J, Banner D, et al. 2013. Infectivity, transmission, and pathology of human-isolated H7N9 influenza virus in ferrets and pigs. Science 341: 183186. doi:10.1126/science.1239844

Zhu W, Li L, Yan Z, Gan T, Li L, Chen R, Chen R, Zheng Z, Hong W, Wang J, et al. 2015. Dual E627 K and D701N mutations in the $\mathrm{PB} 2$ protein of $\mathrm{A}(\mathrm{H} 7 \mathrm{~N} 9)$ influenza virus increased its virulence in mammalian models. Sci Rep 5: 14170. doi:10.1038/srep 14170

Zhu W, Zhou J, Li Z, Yang L, Li X, Huang W, Zou S, Chen W, Wei H, Tang J, et al. 2017. Biological characterisation of the emerged highly pathogenic avian influenza (HPAI) A (H7N9) viruses in humans, in mainland China, 2016 to 2017. Euro Surveill 22: 30533. doi:10.2807/1560-7917.ES .2017 .22 .19 .30533

Zhu W, Dong J, Zhang Y, Yang L, Li X, Chen T, Zhao X, Wei $\mathrm{H}$, Bo H, Zeng X, et al. 2018. A gene constellation in avian influenza A (H7N9) viruses may have facilitated the fifth wave outbreak in China. Cell Rep 23: 909-917. doi:10 .1016/j.celrep.2018.03.081

Zhu W, Feng Z, Chen Y, Yang L, Liu J, Li X, Liu S, Zhou L, Wei H, Gao R, et al. 2019. Mammalian-adaptive mutation NP-Q357K in Eurasian H1N1 swine influenza viruses determines the virulence phenotype in mice. Emerg Microbes Infect 8: 989-999. doi:10.1080/22221751.2019 .1635873 


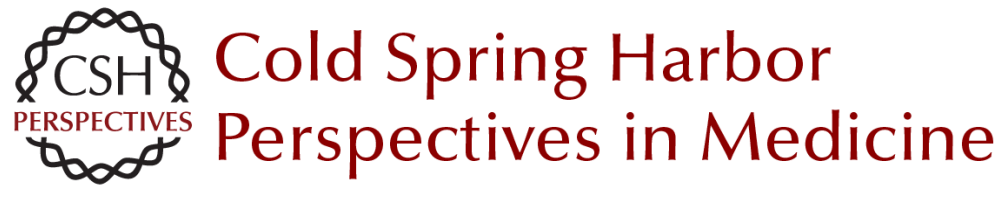

\title{
The Epidemiology, Virology, and Pathogenicity of Human Infections with Avian Influenza Viruses
}

\author{
Dayan Wang, Wenfei Zhu, Lei Yang and Yuelong Shu
}

Cold Spring Harb Perspect Med 2021; doi: 10.1101/cshperspect.a038620 originally published online January 21, 2020

\section{Subject Collection Influenza: The Cutting Edge}

\section{Emerging HxNy Influenza A Viruses William J. Liu, Yan Wu, Yuhai Bi, et al. \\ Equine Influenza Thomas M. Chambers \\ Human Influenza Epidemiology
Sukhyun Ryu and Benjamin J. Cowling}

Host Cell Factors That Interact with Influenza Virus Ribonucleoproteins Ecco Staller and Wendy S. Barclay

Induction and Evasion of Type-I Interferon Responses during Influenza A Virus Infection Raquel Muñoz-Moreno, Carles Martínez-Romero and Adolfo García-Sastre

Structure and Function of Influenza Polymerase Joanna M. Wandzik, Tomas Kouba and Stephen Cusack

H7N9 Influenza Virus in China Chengjun Li and Hualan Chen

H5 Influenza Viruses in Egypt Rabeh El-Shesheny, Ahmed Kandeil, Ahmed Mostafa, et al.
Antivirals Targeting the Neuraminidase Larisa Gubareva and Teena Mohan

Accessory Gene Products of Influenza A Virus Rute M. Pinto, Samantha Lycett, Eleanor Gaunt, et al.

Influenza Immunization in the Context of

Preexisting Immunity Susanne L. Linderman, Ali H. Ellebedy, Carl Davis, et al.

Hemagglutinin Structure and Activities Steven J. Gamblin, Sébastien G. Vachieri, Xiaoli Xiong, et al.

Live Attenuated Cold-Adapted Influenza Vaccines Kanta Subbarao

Next-Generation Influenza Vaccines Masaru Kanekiyo and Barney S. Graham

\section{Selective Genome Packaging Mechanisms of Influenza A Viruses Takeshi Noda}

Systems Biological Analysis of Immune Response to Influenza Vaccination

Mario Cortese, Amy C. Sherman, Nadine G. Rouphael, et al.

For additional articles in this collection, see http://perspectivesinmedicine.cshlp.org/cgi/collection/ 